ISSN 1392-3196 / e-ISSN 2335-8947

Zemdirbyste-Agriculture, vol. 108, No. 4 (2021), p. 339-346

DOI 10.13080/z-a.2021.108.043

\title{
Efficiency of alfalfa seed priming and rhizobial-based liquid inoculants in an Eutric Cambisol
}

\author{
Aneta BUNTIĆ ${ }^{1}$, Olivera STAJKOVIĆ-SRBINOVIĆ ${ }^{1}$, Magdalena KNEŽEVIĆ ${ }^{1}$, \\ Nataša RASULIĆ ${ }^{1}$, Vladan UGRENOVIĆ ${ }^{2}$, Djordje KUZMANOVIĆ ${ }^{1}$, Dušica DELIĆ ${ }^{1}$ \\ ${ }^{1}$ Institute of Soil Science, Department of Microbiology \\ Teodora Drajzera 7, 11000 Belgrade, Serbia \\ E-mail: anetabuntic@gmail.com \\ ${ }^{2}$ Institute of Soil Science, Department of Soil Amelioration and Erosion \\ Teodora Drajzera 7, 11000 Belgrade, Serbia
}

\begin{abstract}
In the last few decades, peat-based bioinoculants have been proven as successful in alfalfa (Medicago sativa L.) seeds inoculation. However, the use of liquid inoculants or pre-inoculated seeds will greatly facilitate the sowing of alfalfa as a small seed legume. Therefore, this study evaluated the effect of four liquid formulations on the survival of Sinorhizobium (Ensifer) meliloti strain 218 during long-term storage. Sodium-alginate (SA) and polyvinylpyrrolidone (PVP) did not affect the growth of $S$. meliloti strain 218 and showed a significant positive effect on its survival in liquid bioinoculants up to 240 days of storage. The effect of seeds pre-inoculation on the efficiency of nitrogen $(\mathrm{N})$ fixation in alfalfa plants in test tube and a two-year field experiment was measured. The field experiment was conducted in 2018 and 2019 in an Eutric Cambisol. The dry weight of alfalfa shoots and total $\mathrm{N}$ content significantly increased in pre-inoculated seeds with all media, compared to the control treatments without pre-inoculation and adding mineral $\mathrm{N}$. In both years of cultivation, the highest total shoot dry weight was achieved by seeds pre-inoculation with SA and PVP 3 months before sowing. Furthermore, in these treatments, shoot dry weight significantly increased compared to the treatment with mineral $\mathrm{N}$ in the $2^{\text {nd }}(2019)$ year.

The results of the research showed that rhizobial bioinoculants with SA and PVP could be used as liquid bioinoculants as well as for successful pre-inoculation of alfalfa seeds.
\end{abstract}

Key words: rhizobia, Medicago sativa, liquid bioinoculants formulation, pre-inoculation, Sinorhizobium meliloti.

\section{Introduction}

During the last decades, the excessive and improper use of chemical fertilisers and pesticides has contributed to the contamination and disturbance of natural balance in agricultural soils. The use of fertilisers based on different types of microorganisms (Rhizobium spp., Azotobacter spp., Bacillus spp., Pseudomonas spp., etc.) has emerged as an effective technology for enhancing the productivity and sustainability of agricultural systems (Andrews et al., 2011; Bargaz et al., 2018; Chinnaswamy et al., 2018).

Rhizobia are soil bacteria from the family of Leguminosae that can establish symbiosis with plant roots and fix atmospheric nitrogen $(\mathrm{N})$ significant to the plant (Biswas, Gresshoff, 2014). Consequentially, the application of rhizobial bioinoculants (biofertiliser) can improve the $\mathrm{N}$ content and crop yield in an environmentally friendly manner (Delić, 2014). In addition, all this contributes to an increase in soil biodiversity (Ugrenović et al., 2020). This is of particular importance in organic production, where it is desirable to feed the plants through soil ecosystems rather than using soluble fertilisers (Council Regulation (EC) No 834/2007). Rhizobial inoculants are also cheaper than inorganic fertilisers; therefore, their application brings fewer financial risks when used as a source to improve the productivity of leguminous crops (Naseer et al., 2019). Conventional microbial bioinoculants are commercially available in the form of a solid fertiliser commonly based on carriers such as peat, clay or coal (Malusá et al., 2012).

However, there are several disadvantages of solid microbiological fertilisers resulting in unpredictable field performance. Uneven distribution of microorganisms on solid carrier particles can lead to an uneven fertilisation effect on crops. The variability in quality and composition of peat and similar carriers should also be considered, as differences in its acidity could severely affect the viability of microorganisms (Malusá et al., 2012). Solid bioinoculants give the greatest effect when the seeds are inoculated just before sowing. However, in today's agricultural practice, farmers resort to application

Please use the following format when citing the article:

Buntić A., Stajković-Srbinović O., Knežević M., Rasulić N., Ugrenović V., Kuzmanović D., Delić D. 2021. Efficiency of alfalfa seed priming and rhizobial-based liquid inoculants in an Eutric Cambisol. Zemdirbyste-Agriculture, 108 (4): $339-346$. DOI 10.13080/z-a.2021.108.043 
of already inoculated seeds in order to avoid seeds inoculation in the field. Therefore, the seed producers offer already inoculated seeds but at a higher price than uninoculated ones. This requires producers to inoculate the seeds a few months in advance during seed finishing processing.

On the other hand, the longevity of microorganisms on pre-inoculated seeds is questionable, as the number of viable bacterial cells decreases during the storage time. Due to the aforementioned disadvantages of solid biofertilisers, the use of liquid bioinoculants has emerged as a more efficient solution (Puwanto et al., 2019). Liquid bioinoculants ensure prolonged survival of microorganisms, which consequently indicates a longer shelf life of the product (Sehrawat et al., 2015). Seeds pre-inoculation also allows easier handling and transport, and growers do not need to worry about rushing and inoculating the seeds at the day of sowing (Sandini et al., 2019). One of the most critical steps are choosing the right carrier for a new bioinoculant formulation, its combination with the microorganisms in the basal medium as well as the selection of a highly effective strain (Bargaz et al., 2018). Bioinoculants for seeds pre-inoculation formulated on carriers such as sodiumalginate (SA), agar (A) and polyvinylpyrrolidone (PVP) are proven to have a great potential, mostly due to their ability to gradually release fertiliser in the soil during the time (Sampson et al., 2016; Bargaz et al., 2018; Ramli, 2019). Furthermore, these carriers do not interfere with the survival of rhizobial cells in the biofertilizer.

Alfalfa (Medicago sativa L.) is grown worldwide as a forage crop due to a high biomass yield, high nutritive value and digestibility. The importance of this crop is also related to the release of $\mathrm{N}$ into the soil and the improvement of the soil structure for future crops (Nešić et al., 2005; Kazemi Khaledi et al., 2019). Alfalfa can establish a symbiosis with Sinorhizobium meliloti and fix atmospheric $\mathrm{N}$ significant to the plant. Alfalfa is a small-seeded leguminous plant, and artificial seeds inoculation with solid peat rhizobial bioinoculants can pose some difficulties such as seeds sticking and uneven sowing. Therefore, application of liquid bioinoculants or using pre-inoculated seeds would highly facilitate the sowing of alfalfa. In our previous study (Buntić et al., 2019), pre-inoculation of alfalfa seeds with liquid rhizobial bioinoculants (combination of agar and $S$. meliloti strain $\mathrm{L} 3 \mathrm{Si}$ ) one month before sowing enhanced the quality of alfalfa crops.

The aim of the experiment was to develop a liquid rhizobial bioinoculant for pre-inoculation of alfalfa seeds. Different media formulations with $S$. meliloti strain 218 were tested. The growth and survival of this strain under different storage temperature conditions were evaluated over a period of 240 days. The effect of pre-inoculation of alfalfa seeds by selected bioinoculants on the efficiency of $\mathrm{N}$ fixation in alfalfa plants was also evaluated in test tube and field experiment.

\section{Materials and methods}

Rhizobium culture was prepared using efficient nitrogen (N) fixing Sinorhizobium meliloti strain 218 for alfalfa (Medicago sativa L.) cultivar K28 seeds. It was selected from the Department of Microbiology, the Institute of Soil Science collection (ISS WDCM375Collection of Bacteria), Serbia. The $S$. meliloti strain 218 was grown in Erlenmeyer flasks in yeast mannitol broth (YMB): mannitol $\left(10 \mathrm{~g} \mathrm{~L}^{-1}\right), \mathrm{K}_{2} \mathrm{HPO}\left(0.5 \mathrm{~g} \mathrm{~L}^{-1}\right), \mathrm{MgSO}$ $\times 7 \mathrm{H}_{2} \mathrm{O}\left(0.2 \mathrm{~g} \mathrm{~L}^{-1}\right), \mathrm{NaCl}\left(0.1 \mathrm{~g} \mathrm{~L}^{-1}\right), \mathrm{CaCO}_{3}\left(0.2 \mathrm{~g} \mathrm{~L}^{-1}\right)$ and fresh yeast extract $\left(100 \mathrm{~mL}, 30 \mathrm{~g} \mathrm{~L}^{-1}\right)$, on a rotary shaker $(125 \mathrm{rpm})$ at $28^{\circ} \mathrm{C}$ temperature for $48 \mathrm{~h}$ (Buntić et al., 2019).
Preparation of liquid rhizobial bioinoculants. The basal medium for the formulation of liquid inoculants (LI) contained all components of YMB, except the mannitol $\left(10 \mathrm{~g} \mathrm{~L}^{-1}\right)$. Mannitol was added in concentration of $1 \mathrm{~g} \mathrm{~L}^{-1}$ and presented one of the four tested formulations of inoculants for seeds pre-inoculation. Other three media were prepared by adding the following additives: liquid inoculant (LI) with agar (LI-A; $1 \mathrm{~g} \mathrm{~L}^{-1}$ ), LI with sodiumalginate (LI-SA; $1 \mathrm{~g} \mathrm{~L}^{-1}$ ) and LI with polyvinylpyrrolidone (LI-PVP; $10 \mathrm{~g} \mathrm{~L}^{-1}$ ). Liquid rhizobial bioinoculants were prepared by adding $1 \%$ inoculum of $S$. meliloti strain 218 (which was grown in YMB) to $50 \mathrm{~mL}$ of various media. All bioinoculants were placed in a rotary shaker $(125 \mathrm{rpm})$ at $28^{\circ} \mathrm{C}$ temperature for $48 \mathrm{~h}$.

Rhizobium survival evaluation after prolonged storage. The survival of $S$. meliloti strain 218 in four different media formulations was tested. Prepared bioinoculants were stored at $4^{\circ} \mathrm{C}$ and $22^{\circ} \mathrm{C}$ temperatures for 240 days ( 8 months). The number of viable rhizobium cells after each 30 days of storage was determined by plating appropriate bioinoculant dilutions $\left(10^{-6}, 10^{-7}, 10^{-8}\right.$ and $10^{-9}$ ) on YMA and incubation of $48 \mathrm{~h}$. All measurements were performed in triplicate. Additionally, after the expiration of storage time, acidity $(\mathrm{pH})$ was measured in all media.

Pre-inoculation of alfalfa seeds and test tube experiment. The pre-inoculation of alfalfa seeds was carried out by adding $250 \mu \mathrm{L}$ of selected liquid inoculants (LI, LI-A, LI-SA and LI-PVP) to $2 \mathrm{~g}$ of seeds. Dried seeds were stored at $22^{\circ} \mathrm{C}$ temperature during a period of 0 (LI-0, LI-A0, LI-SA0 and LI-PVP0), 1 (LI-1, LIA1, LI-SA1 and LI-PVP1), 2 (LI-2, LI-A2, LI-SA2 and LI-PVP2) and 3 (LI-3, LI-A3, LI-SA3 and LI-PVP3) months. Pre-inoculated seeds (10 seeds per treatment in triplicate) were sown every month in glass tubes with Jensen's medium agar. The pre-inoculation efficiency by examination of nodulation, plant height, shoot dry weight (SDW) and $\mathrm{N}$ content in SDW $\left(\mathrm{N}_{\text {tot }}\right.$ ) was evaluated. $\mathrm{N}_{\text {tot }}$ content was calculated by percentage of shoot $\mathrm{N}$, which was determined from dried and ground plant samples (Horneck, Miller, 1988) using the Vario EL III Element Analyzer(ElementalAnalysensysteme GmbH, Germany). The results were compared with two control treatments: non-inoculated seeds grown in Jensen's medium agar without $(\varnothing \varnothing)$ and with $(\varnothing \mathrm{N})$ mineral $\mathrm{N}\left(\mathrm{N}_{\text {min }}\right)$ fertiliser in $0.05 \% \mathrm{KNO}_{3}$ (potassium nitrate) (Vincent, 1970).

Field experiment. For the field experiment, preinoculated alfalfa seeds with the media formulations of LI, LI-PVP and LI-SA and stored during zero $(0)$, one $(-1)$, two $(-2)$ and three $(-3)$ months were selected. The experiment was established in 2018 in the field, where alfalfa had not been sown so far, located in moderatecontinental climate zone, $32 \mathrm{~km}$ from Belgrade in the village of Mala Ivanča (N 49 37'612", E 46 $95^{\prime} 29^{\prime \prime}$ ) in Eutric Cambisol (WRB, 2014) and monitored for two (2018-2019) years.

According to the data of the Meteorological Observatory Sopot, Republic Hydrometeorological Service of Serbia, average monthly air temperature (minimal and maximal) and precipitation for the experimental period are presented in Figure 1. Average monthly maximal and minimal temperatures for the two-year experimental period were $21.83^{\circ} \mathrm{C}$ and $7.91^{\circ} \mathrm{C}$, respectively. Average sum of precipitation for this period was $657 \mathrm{~mm}$.

Basic soil fertility parameters were: $\mathrm{pH}_{\mathrm{KCl}} 6.22$, $\mathrm{pH}_{\mathrm{H} 2 \mathrm{O}} 7.10$, organic C 2.11\%, available P $22.40 \mathrm{mg}$ $100 \mathrm{~g}^{-1}$, available $\mathrm{K} 26.17 \mathrm{mg} 100 \mathrm{~g} \mathrm{~g}^{-1}$, N content $0.298 \%$ and $\mathrm{C}$ to $\mathrm{N}$ ratio 11.06. Two control treatments (with non-inoculated seeds) were also provided without (ØØ) and with (ØN) $\mathrm{N}_{\min }$ fertiliser application. The experiment was laid out in a completely randomized design in 


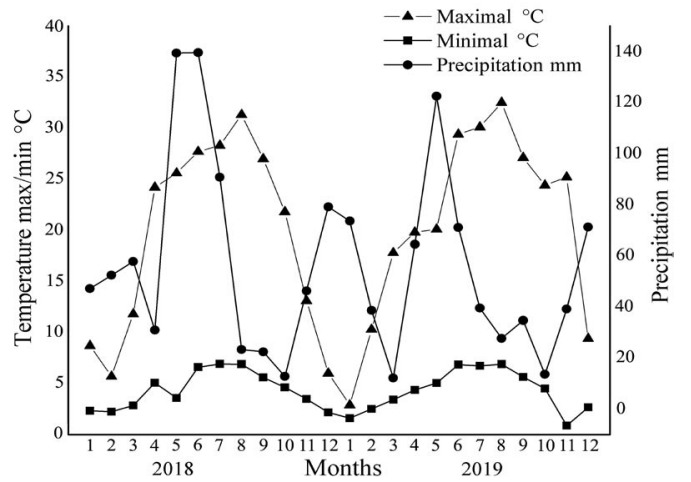

Figure 1. Air temperature and precipitation for the region of the field experiment (according to the Republic Hydrometeorological Service of Serbia)

three replicates (for all treatments including controls). The alfalfa was planted in $1 \mathrm{~m}^{2}$ plots at a sowing rate of $20 \mathrm{~kg} \mathrm{ha}^{-1}$. The experimental field was not irrigated, fertilisers and pesticides were not used. During 2018 and 2019, three times a year, alfalfa biomass was collected (cut) at the full-bloom stage, and SDW and the N content in SDW $\left(\mathrm{N}_{\text {tot }}\right)$ were determined. Each cutting of whole plots was carried out manually by cutting the plant at a height of 3-5 cm. Plant shoots were dried in an oven at $70^{\circ} \mathrm{C}$ temperature to constant weight, and the average dry weight per treatment was calculated. $\mathrm{N}_{\text {tot }}$ content was calculated by percentage of shoot $\mathrm{N}$ (explained above).
Statistical analysis. To examine the differences between each media formulation, the effect of preinoculation of alfalfa seeds was evaluated by one- and two-way analysis of variance (ANOVA) followed by post hoc Duncan's test. All data represented are the mean \pm standard deviation (SD) of three replicates $(n=3)$ of each treatment. The data were processed by statistical software package SPSS, version 17.0 (SPSS Inc., USA).

\section{Results}

Survival of Sinorhizobium meliloti strain 218 in liquid media under different storage conditions. The effect of three additives: agar (A), sodium-alginate (SA) and polyvinylpyrrolidone (PVP), in liquid rhizobial bioinoculants on the viable cell count of $S$. meliloti strain 218 after $48 \mathrm{~h}$ of incubation was tested (Figure 2).

The viable cell counts ranged from $4.75 \times 10^{8}$ (LI-A) to $8.75 \times 10^{8}(\mathrm{LI}-\mathrm{PVP})$ cell $\mathrm{mL}^{-1}$ (presented as 0 days in Figure 2). In addition, the effects of different storage time and storage temperatures on the survival rate of $S$. meliloti strain 218 in four liquid formulations were monitored. Compared to the initial number of viable bacterial cells in all formulations, the highest decrease of viable cells of $S$. meliloti strain 218 was in LI-A treatment at both storage temperatures; it was slightly higher than $1 \times 10^{8}$ cell $\mathrm{mL}^{-1}$. The number of viable rhizobia declined slightly in LI-SA and LI-PVP treatments during storage time from 60 to 240 days at $4^{\circ} \mathrm{C}$ temperature. Maximum cell survival ranged from $61.73 \%$ in LI-SA to $38.08 \%$
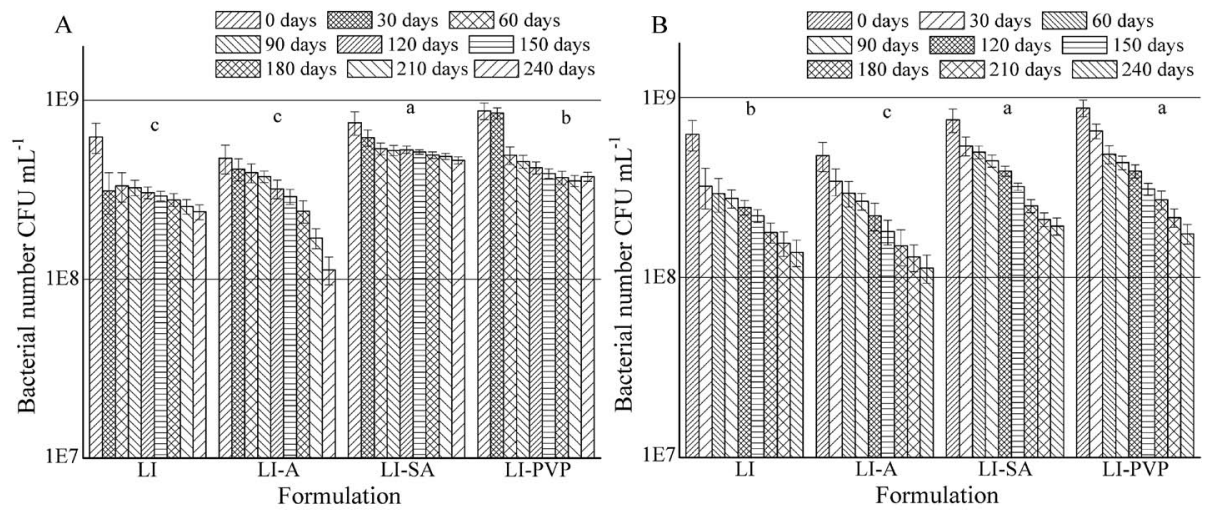

Note. A - agar, SA - sodium-alginate, PVP - polyvinylpyrrolidone; treatments followed by the same letter are not significantly different $(P>0.05)$; the bars above the columns denote the standard deviation (SD).

Figure 2. Survival of Sinorhizobium meliloti strain 218 in four different liquid inoculants (LI) formulations during storage at $4^{\circ} \mathrm{C}(\mathrm{A})$ and $22^{\circ} \mathrm{C}(\mathrm{B})$ temperatures

in LI (Figure 2A) after 240 days of storage at $4^{\circ} \mathrm{C}$ temperature. At higher storage temperature, the survival of $S$. meliloti strain 218 was lower and it ranged from $25.73 \%$ in LI-SA to $20 \%$ in LI-PVP.

ANOVA showed significant differences $(P<0.001)$ in the number of viable bacterial cells between media formulation during storage at both temperatures. There were no differences in the changes in the number of bacteria between the LI and LI-A and LI-SA and LI-PVP treatments during storage at $4^{\circ} \mathrm{C}$ and $22^{\circ} \mathrm{C}$ temperatures, respectively. In addition, the $\mathrm{pH}$ values remained unchanged in all media formulations and were between 7.2 and 7.9 after the expiration of storage time. However, in all treatments, the number of viable bacterial cells of $S$. meliloti strain 218 was still above the number given by local regulation (Official Gazette of the Republic of Serbia Nos. 30/2017-13 and 31/2018-86).

Pre-inoculation effect on alfalfa seeds. In test tube experiment, the effect of pre-inoculation of alfalfa seeds with four different liquid rhizobial bioinoculants on the plant nodulation, plant height, shoot dry weight (SDW) and $\mathrm{N}$ content in SDW $\left(\mathrm{N}_{\text {tot }}\right)$ was estimated (Table 1).

The nodulation test with pre-inoculated seeds stored up to 3 months showed nodulation in all tested treatments on alfalfa roots. The percentage of nodulation for the seeds inoculated on the day of sowing and pre-inoculated seeds stored for 1, 2 and 3 months were 100\%, except three (LI3, LI-A3 and LI-A2) treatments. Using agar as supplement in liquid rhizobial bioinoculants for seeds coating and their storage more than 1 month was not satisfactory.

Applied treatments had a significant effect $(P$ $<0.001$ ) on the plant height, SDW and $\mathrm{N}_{\text {tot }}$ (Table 1). Compared to the control treatment without $\mathrm{N}(\varnothing \varnothing)$, significant increase of SDW using the pre-inoculated seeds stored for up to 3 months before sowing was observed in all pre-inoculated treatments. Generally, the SDW increased 2.57-4.53-fold compared to the control treatment (ØØ), except LI-3, LI-1, LI-A3, LI-A1, LI- 
Table 1. The effect of seeds pre-inoculation on alfalfa growth and its N-fixing efficiency during test tube experiment

\begin{tabular}{|c|c|c|c|c|}
\hline Treatment & $\begin{array}{c}\text { Nodulation } \\
\% \\
\end{array}$ & $\begin{array}{l}\text { Plant height } \\
\mathrm{cm} \mathrm{plant}^{-1}\end{array}$ & $\begin{array}{c}\text { SDW } \\
\text { mg plant }^{-1}\end{array}$ & $\begin{array}{c}\mathrm{N}_{\text {tot }} \\
\text { mg plant }^{-1}\end{array}$ \\
\hline LI-3 & 90 & $17.80 \pm 1.06 \mathrm{bc}$ & $11.53 \pm 0.28 \mathrm{i}$ & $0.42 \pm 0.03 \mathrm{f}$ \\
\hline LI-2 & 100 & $17.73 \pm 1.57 \mathrm{bcd}$ & $13.77 \pm 0.25 \mathrm{f}$ & $0.54 \pm 0.03 \mathrm{~d}$ \\
\hline LI-1 & 100 & $16.87 \pm 1.47 \mathrm{~b}-\mathrm{e}$ & $12.51 \pm 0.02 \mathrm{~g}$ & $0.49 \pm 0.02 \mathrm{f}$ \\
\hline LI-0 & 100 & $17.33 \pm 2.23 \mathrm{~b}-\mathrm{e}$ & $13.67 \pm 0.23 \mathrm{f}$ & $0.55 \pm 0.02 \mathrm{~d}$ \\
\hline LI-A3 & 80 & $14.63 \pm 0.85 \mathrm{de}$ & $9.95 \pm 0.02 \mathrm{j}$ & $0.35 \pm 0.02 \mathrm{~h}$ \\
\hline LI-A2 & 90 & $15.50 \pm 1.05 \mathrm{cde}$ & $13.72 \pm 0.25 \mathrm{f}$ & $0.50 \pm 0.02 \mathrm{e}$ \\
\hline LI-A1 & 100 & $14.33 \pm 1.04 \mathrm{e}$ & $11.35 \pm 0.29 \mathrm{i}$ & $0.49 \pm 0.01$ ef \\
\hline LI-A0 & 100 & $15.92 \pm 1.94 \mathrm{cde}$ & $12.43 \pm 0.04 \mathrm{~g}$ & $0.55 \pm 0.02 \mathrm{~d}$ \\
\hline LI-PVP3 & 100 & $18.67 \pm 2.08 \mathrm{bc}$ & $14.58 \pm 0.01 \mathrm{~d}$ & $0.47 \pm 0.02 \mathrm{ef}$ \\
\hline LI-PVP2 & 100 & $19.17 \pm 3.40 \mathrm{~b}$ & $14.24 \pm 0.03 \mathrm{e}$ & $0.48 \pm 0.01$ ef \\
\hline LI-PVP1 & 100 & $19.67 \pm 1.53 b$ & $11.43 \pm 0.02 \mathrm{i}$ & $0.62 \pm 0.01 \mathrm{c}$ \\
\hline LI-PVP0 & 100 & $26.10 \pm 2.13 \mathrm{a}$ & $24.14 \pm 0.29 \mathrm{a}$ & $1.08 \pm 0.02 \mathrm{a}$ \\
\hline LI-SA3 & 100 & $17.50 \pm 0.70 \mathrm{bcd}$ & $14.70 \pm 0.27 \mathrm{~d}$ & $0.47 \pm 0.01$ ef \\
\hline LI-SA2 & 100 & $17.93 \pm 0.83 \mathrm{bc}$ & $11.989 \pm 0.04 \mathrm{~h}$ & $0.33 \pm 0.02 \mathrm{~h}$ \\
\hline LI-SA1 & 100 & $17.83 \pm 1.26 \mathrm{bc}$ & $12.82 \pm 0.02 \mathrm{~g}$ & $0.38 \pm 0.02 \mathrm{~g}$ \\
\hline LI-SA0 & 100 & $18.13 \pm 0.91 \mathrm{bc}$ & $15.99 \pm 0.03 \mathrm{c}$ & $0.61 \pm 0.01 \mathrm{c}$ \\
\hline$\varnothing \varnothing$ & 0 & $6.83 \pm 1.26 \mathrm{f}$ & $5.32 \pm 0.02 \mathrm{k}$ & $0.09 \pm 0.01 \mathrm{i}$ \\
\hline \multirow[t]{2}{*}{$\varnothing \mathrm{N}$} & 0 & $26.50 \pm 1.80 \mathrm{a}$ & $21.43 \pm 0.03 b$ & $0.79 \pm 0.02 b$ \\
\hline & One-way ANC & $19.78 * * *$ & $1767.54 * * *$ & $428.97 * * *$ \\
\hline
\end{tabular}

Note. Liquid inoculant (LI) without additives: LI-A - with agar, LI-PVP - with polyvinylpyrrolidone, LI-SA - with sodiumalginate; seeds storage: zero (0), one (1), two (2) and three (3) months; control ØØ - without N, ØN - with $\mathrm{N}_{\min }\left(0.05 \% \mathrm{KNO}_{3}\right)$; SDW - shoot dry weight; $\mathrm{N}_{\text {tot }}-\mathrm{N}$ content in SDW; results were represented as mean $\pm \mathrm{SD}$; mean values followed by the same letter in the columns are not significantly different $(P>0.05)$; one-way ANOVA shows $F$ values; *** - significant at $P<0.001$.

A0, LI-PVP1, LI-SA2 and LI-SA1 treatments. Most treatments gave $\mathrm{N}_{\text {tot }}$ content between 0.468 (LI-SA3) and 0.616 (LI-PVP1) mg plant $^{-1} \mathrm{~N}$. The highest $\mathrm{N}_{\text {tot }}$ content of $1.08 \mathrm{mg}$ plant $^{-1} \mathrm{~N}$ was obtained in LI-PVP0 treatment.

Two-way ANOVA showed that media formulation and storage time of seeds as well as their interactions significantly influenced plant height, SDW and $\mathrm{N}_{\text {tot }}$ content (Table 2).
According to the tube experiment, where nodulation was decreased and shoot height and SDW value were lowest (Table 1) as well as the reduced survival of bacteria over prolonged time of storage in both temperatures (Figure 2), LI-A treatments were not included in the field experiment.

In the field experiment, in both experimental years, total SDW for all cuttings $\left(\mathrm{SDW}_{\text {tot }}\right)$ per year of

Table 2. The results of two-way ANOVA for plant height, shoot dry weigh (SDW) and total nitrogen $\left(\mathrm{N}_{\text {tot }}\right)$ content of alfalfa plants

\begin{tabular}{|c|c|c|c|c|c|c|c|c|c|c|}
\hline & \multirow[t]{2}{*}{ df } & \multicolumn{3}{|c|}{ Sum of square } & \multicolumn{3}{|c|}{ Mean square } & \multicolumn{3}{|c|}{$F$-value } \\
\hline & & $\begin{array}{l}\text { Plant } \\
\text { height }\end{array}$ & SDW & $\mathrm{N}_{\text {tot }}$ & $\begin{array}{l}\text { Plant } \\
\text { height }\end{array}$ & SDW & $\mathrm{N}_{\text {tot }}$ & $\begin{array}{l}\text { Plant } \\
\text { height }\end{array}$ & SDW & $\mathrm{N}_{\text {tot }}$ \\
\hline Media formulation & 3 & 204.69 & 113.49 & 0.35 & 68.23 & 37.83 & 0.12 & $24.92 * * *$ & $1196.20 * * *$ & $375.81 * * *$ \\
\hline Storage time & 3 & 39.91 & 153.08 & 0.52 & 13.30 & 51.03 & 0.17 & $4.86^{* *}$ & $1613.50 * * *$ & $567.01 * * *$ \\
\hline $\begin{array}{l}\text { Media formulation } \\
\times \text { storage time }\end{array}$ & 9 & 76.94 & 190.70 & 0.43 & 8.55 & 21.19 & 0.05 & $3.12 * *$ & $669.99 * * *$ & $156.00 * * *$ \\
\hline Error & 32 & 87.62 & 1.01 & 0.01 & 2.74 & 0.03 & 0.0003 & & & \\
\hline Total & 47 & 409.17 & 458.28 & 1.31 & & & & & & \\
\hline
\end{tabular}

Significant at $* *-P<0.01$ and $* * *-P<0.001 ; \mathrm{df}-$ degree of freedom

all pre-inoculated treatments was significantly higher compared to the control treatment without $\mathrm{N}(\varnothing \varnothing)$ (Tables 3 and 4). In the $1^{\text {st }}$ year of alfalfa cultivation in the field, SDW tot for inoculated treatments ranged between 6.82 (LI-0) and 7.42 (LI-SA3) t ha- ${ }^{-1}$, respectively. The highest values of SDW ${ }_{\text {tot }}$ were given in LI-SA3 in the $1^{\text {st }}$ year (Table 3 ) and in LI-PVP in the $2^{\text {nd }}$ year (Table 4 ). On the other hand, $\mathrm{SDW}_{\text {tot }}$ in all treatments was lower compared to the control treatment with $\mathrm{N}_{\min }(\varnothing \mathrm{N})$ (Table 3). According to two-way ANOVA, the medium formulation and storage time significantly influenced SDW at the $2^{\text {nd }}$ and $3^{\text {rd }}$ cutting, while their interaction showed no significance. Further, in the $2^{\text {nd }}$ cutting, both factors and their interaction showed significant effect $(P<0.05)$ on $\mathrm{N}_{\text {tot }}$ content.

In the $2^{\text {nd }}$ year, SDW tot $_{\text {for inoculated treatments }}$ ranged between 9.97 (LI-0 and LI-SA1) and 11.43 (LIPVP3) $\mathrm{t} \mathrm{ha}^{-1}$. The SDW of alfalfa was significant higher in LI-PVP3 (11.43 tha ${ }^{-2}$ ) and LI-SA3 (11.38 $\mathrm{tha}^{-2}$ ) compared to the control treatment $(\varnothing \varnothing)$ as well as compared to the treatment with $\mathrm{N}_{\min }(\varnothing \mathrm{N})\left(9.64 \mathrm{t} \mathrm{ha}^{-2}\right)$ (Table 4). Preinoculation up to 2 months before the sowing as well as inoculation on the day of sowing $\left(1^{\text {st }}\right.$ and $2^{\text {nd }}$ cutting) gave satisfactory results showing no significant differences in comparison with the control treatment $(\varnothing \mathrm{N})$ using liquid rhizobial bioinoculants with SA and PVP.

In the $2^{\text {nd }}$ year of alfalfa cultivation, the $\mathrm{N}_{\text {tot }}$ content was higher $14 \%$ in LI-SA3 and $17 \%$ in LI-PVP3 compared to the control treatment with $\mathrm{N}_{\text {min }}(\varnothing \mathrm{N})$. In this regard, the pre-inoculation of alfalfa seeds with new rhizobial bioinoculants of these two formulations gave the highest yield and quality of alfalfa. The medium formulation was significant at the $1^{\text {st }}$ and $3^{\text {rd }}$ cutting for SDW, while their interaction with storage time showed significance only for the $1^{\text {st }}$ cutting in the $2^{\text {nd }}$ year of alfalfa cultivation. The storage time showed significance only in the $3^{\text {rd }}$ cutting for SDW, while the individual factors and their interaction were not significant for $\mathrm{N}_{\text {tot }}$ content in all cuttings. If the comparison is made between years, the total SDW was higher in the $2^{\text {nd }}$ year than in the $1^{\text {st }}$ one (Tables 3-5). In addition, all treatments showed higher values for the $\mathrm{SDW}_{\text {tot }}$ and $\mathrm{N}_{\text {tot }}$ content than control without $\mathrm{N}(\varnothing \varnothing)$ in the two-year average (Table 5).

ANOVA revealed significant effect of treatments, years and the treatment and year interaction on the SDW and $\mathrm{N}_{\text {tot }}$ content (Table 5). According to two-year average for $\mathrm{SDW}_{\text {tot }}$ and $\mathrm{N}_{\text {tot }}$ content, the best treatment was LISA3 followed by LI-PVP3 treatment. 
Table 3. The effect of seeds pre-inoculation on field alfalfa growth and its N-fixing efficiency in the $1^{\text {st }}$ year (2018) of the experiment

\begin{tabular}{|c|c|c|c|c|c|c|c|}
\hline \multirow{3}{*}{ Treatment } & \multicolumn{6}{|c|}{ Cutting } & \multirow[b]{3}{*}{$\begin{array}{c}\mathrm{SDW}_{\text {fot }} \\
\mathrm{tha}^{\text {t- }}\end{array}$} \\
\hline & \multicolumn{2}{|c|}{$1^{\text {st }}$} & \multicolumn{2}{|c|}{$2^{\text {nd }}$} & \multicolumn{2}{|c|}{$3^{\text {rd }}$} & \\
\hline & $\begin{array}{l}\mathrm{SDW} \\
\mathrm{g} \mathrm{m}^{-2}\end{array}$ & $\begin{array}{l}\mathrm{N}_{\text {tot }} \\
\mathrm{g} \mathrm{m}^{-2}\end{array}$ & $\begin{array}{l}\mathrm{SDW} \\
\mathrm{g} \mathrm{m}^{-2}\end{array}$ & $\begin{array}{l}\mathrm{N}_{\text {tot }} \\
\mathrm{g} \mathrm{m}^{-2}\end{array}$ & $\begin{array}{l}\mathrm{SDW} \\
\mathrm{g} \mathrm{m}^{-2}\end{array}$ & $\begin{array}{l}\mathrm{N}_{\text {tot }} \\
\mathrm{g} \mathrm{m}^{-2}\end{array}$ & \\
\hline LI-3 & $138.33 \pm 37.58 \mathrm{abc}$ & $5.87 \pm 1.65 \mathrm{a}-\mathrm{e}$ & $274.67 \pm 5.03 \mathrm{~cd}$ & $10.62 \pm 1.46 \mathrm{~b}-\mathrm{e}$ & $196.67 \pm 20.82 \mathrm{ef}$ & $8.23 \pm 0.72 \mathrm{e}$ & $6.10 \pm 0.17 \mathrm{~cd}$ \\
\hline LI-2 & $152.67 \pm 20.53 \mathrm{ab}$ & $7.59 \pm 0.98 \mathrm{ab}$ & $269.33 \pm 11.24$ cde & $11.22 \pm 0.87 \mathrm{a}-\mathrm{e}$ & $155.60 \pm 41.33 \mathrm{~g}$ & $8.16 \pm 0.24 \mathrm{e}$ & $5.78 \pm 0.56 \mathrm{de}$ \\
\hline LI-1 & $154.00 \pm 15.10 \mathrm{ab}$ & $7.78 \pm 1.01 \mathrm{a}$ & $250.20 \pm 10.01 \mathrm{de}$ & $9.38 \pm 0.52 \mathrm{def}$ & $236.67 \pm 17.08 \mathrm{bcd}$ & $10.06 \pm 0.91 \mathrm{bcd}$ & $6.41 \pm 0.58 \mathrm{bc}$ \\
\hline LI-0 & $149.33 \pm 5.03 \mathrm{ab}$ & $6.42 \pm 1.02 \mathrm{a}-\mathrm{d}$ & $206.67 \pm 20.30 \mathrm{f}$ & $8.01 \pm 0.51 \mathrm{f}$ & $189.44 \pm 10.84 \mathrm{fg}$ & $8.13 \pm 0.32 \mathrm{e}$ & $5.45 \pm 0.08 \mathrm{de}$ \\
\hline LI-PVP3 & $142.00 \pm 19.29 \mathrm{abc}$ & $6.49 \pm 0.89 \mathrm{a}-\mathrm{d}$ & $290.20 \pm 10.01 b c$ & $12.23 \pm 0.84 \mathrm{abc}$ & $249.33 \pm 22.03 a b c$ & $9.87 \pm 1.12 \mathrm{~d}-\mathrm{e}$ & $6.82 \pm 0.44 b c$ \\
\hline LI-PVP2 & $160.00 \pm 64.71 \mathrm{ab}$ & $6.45 \pm 2.94 \mathrm{a}-\mathrm{d}$ & $263.33 \pm 15.28$ cde & $9.76 \pm 2.59 \mathrm{c}-\mathrm{f}$ & $236.00 \pm 6.93 \mathrm{bcd}$ & $10.12 \pm 1.24 b c$ & $6.59 \pm 0.24 b c$ \\
\hline LI-PVP1 & $111.00 \pm 16.46 b c$ & $4.94 \pm 0.89 \mathrm{c}-\mathrm{e}$ & $257.60 \pm 8.51 \mathrm{de}$ & $10.33 \pm 1.04 c-f$ & $202.13 \pm 21.26$ def & $8.32 \pm 1.44 \mathrm{de}$ & $5.71 \pm 0.46 \mathrm{de}$ \\
\hline LI-PVP0 & $108.67 \pm 5.77 b c$ & $4.50 \pm 0.57 \mathrm{de}$ & $269.60 \pm 13.8$ cde & $11.49 \pm 0.83 \mathrm{a}-\mathrm{d}$ & $213.87 \pm 14.89 c-f$ & $8.93 \pm 0.82$ cde & $5.92 \pm 0.63 \mathrm{de}$ \\
\hline LI-SA3 & $170.67 \pm 14.05 \mathrm{a}$ & $7.36 \pm 1.54 \mathrm{abc}$ & $305.7 \pm 19.25 \mathrm{ab}$ & $13.43 \pm 2.08 \mathrm{a}$ & $265.33 \pm 8.08 \mathrm{ab}$ & $10.87 \pm 0.72 \mathrm{ab}$ & $7.42 \pm 0.32 \mathrm{ab}$ \\
\hline LI-SA2 & $148.67 \pm 11.12 \mathrm{ab}$ & $7.11 \pm 0.45 a b c$ & $273.87 \pm 21.17 \mathrm{~cd}$ & $10.59 \pm 0.96 \mathrm{~b}-\mathrm{e}$ & $228.53 \pm 28.11 b-\mathrm{e}$ & $10.28 \pm 0.90 \mathrm{bc}$ & $6.51 \pm 0.85 b c$ \\
\hline LI-SA1 & $141.00 \pm 6.08 \mathrm{abc}$ & $6.06 \pm 0.70 \mathrm{a}-\mathrm{e}$ & $238.67 \pm 18.63 \mathrm{e}$ & $8.90 \pm 1.91$ ef & $239.07 \pm 23.38 \mathrm{bcd}$ & $9.76 \pm 0.86 \mathrm{~b}-\mathrm{e}$ & $6.19 \pm 0.09 \mathrm{~cd}$ \\
\hline LI-SA0 & $124.00 \pm 48.04 \mathrm{abc}$ & $5.02 \pm 2.17 \mathrm{~b}-\mathrm{e}$ & $276.73 \pm 17.55 \mathrm{bcd}$ & $12.14 \pm 1.08 \mathrm{abc}$ & $205.00 \pm 18.03 \mathrm{def}$ & $8.29 \pm 0.69 \mathrm{de}$ & $6.06 \pm 0.23 \mathrm{cde}$ \\
\hline ØØ & $96.33 \pm 7.09 \mathrm{c}$ & $3.81 \pm 0.37 \mathrm{e}$ & $130.33 \pm 10.00 \mathrm{~g}$ & $4.77 \pm 0.75 \mathrm{~g}$ & $117.93 \pm 16.62 \mathrm{~h}$ & $4.48 \pm 0.35 \mathrm{f}$ & $3.45 \pm 0.22 \mathrm{f}$ \\
\hline$\varnothing \mathrm{N}$ & $173.33 \pm 15.28 \mathrm{a}$ & $7.77 \pm 0.72 \mathrm{a}$ & $322.13 \pm 33.03 \mathrm{a}$ & $12.86 \pm 0.96 \mathrm{ab}$ & $284.67 \pm 17.47 \mathrm{a}$ & $12.06 \pm 0.88 \mathrm{a}$ & $7.80 \pm 0.40 \mathrm{a}$ \\
\hline $\begin{array}{l}\text { One-way } \\
\text { ANOVA }\end{array}$ & $2.270^{*}$ & $2.750 *$ & $25.869 * * *$ & $8.636^{* * *}$ & $12.979 * * *$ & $12.769 * * *$ & $15.567 * * *$ \\
\hline \multicolumn{8}{|c|}{ Two-way ANOVA } \\
\hline $\begin{array}{c}\text { Medium } \\
\text { formulation }\end{array}$ & $1.452 \mathrm{~ns}$ & $2.628 \mathrm{~ns}$ & $3.557^{*}$ & $3.579^{*}$ & $8.879 * *$ & $1.493 \mathrm{~ns}$ & $2.450 \mathrm{~ns}$ \\
\hline Storage time & $1.750 \mathrm{~ns}$ & $2.423 \mathrm{~ns}$ & $4.109 *$ & $3.215^{*}$ & $3.481 *$ & $3.048^{*}$ & $8.434 * *$ \\
\hline $\begin{array}{c}\text { Medium } \\
\text { formulation } \\
\times \text { storage time }\end{array}$ & $1.082 \mathrm{~ns}$ & $8 \mathrm{~ns}$ & ns & $2.861^{*}$ & $1.701 \mathrm{~ns}$ & $2.552 *$ & $1.257 \mathrm{~ns}$ \\
\hline
\end{tabular}

Note. Explanations under Table 1; results were represented as mean $\pm \mathrm{SD}$; significant at $*-P<0.05, * *-P<0.01$ and *** $-P<0.001$, ns - not significant; one- and two-way ANOVA shows $F$ values.

Table 4. The effect of seeds pre-inoculation on field alfalfa growth and its N-fixing efficiency in the $2^{\text {nd }}$ year (2019) of the experiment

\begin{tabular}{|c|c|c|c|c|c|c|c|}
\hline \multirow{3}{*}{ Treatment } & \multicolumn{6}{|c|}{ Cutting } & \multirow[b]{3}{*}{$\begin{array}{l}\mathrm{SDW}_{\text {fot }} \\
\mathrm{tha}^{\text {f-t }}\end{array}$} \\
\hline & \multicolumn{2}{|c|}{$1^{\text {st }}$} & \multicolumn{2}{|c|}{$2^{\text {nd }}$} & \multicolumn{2}{|c|}{$3^{\text {rd }}$} & \\
\hline & $\begin{array}{l}\text { SDW } \\
\mathrm{g} \mathrm{m}^{-2}\end{array}$ & $\mathrm{~g} \mathrm{~m}_{\text {tot }} \mathrm{N}$ & $\begin{array}{l}\text { SDW } \\
\mathrm{g} \mathrm{m}^{-2}\end{array}$ & 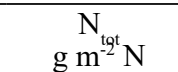 & $\begin{array}{l}\text { SDW } \\
\mathrm{g} \mathrm{m}^{-2}\end{array}$ & $\underset{g^{\mathrm{m}^{-2} \mathrm{t}} \mathrm{N}}{\mathrm{N}_{\mathrm{N}}}$ & \\
\hline LI-3 & $203.47 \pm 35.33 \mathrm{~cd}$ & $7.98 \pm 1.72 b$ & $423.33 \pm 23.09 \mathrm{bc}$ & $16.12 \pm 1.42 \mathrm{a}$ & $373.33 \pm 5.77 \mathrm{abc}$ & $15.30 \pm 1.53 \mathrm{ab}$ & $10.00 \pm 0.63 \mathrm{~b}-\mathrm{e}$ \\
\hline LI-2 & $213.33 \pm 20.82 \mathrm{bcd}$ & $8.36 \pm 0.79 a b$ & $436.67 \pm 15.28 \mathrm{abc}$ & $16.25 \pm 3.14 \mathrm{a}$ & $383.33 \pm 95.04 \mathrm{abc}$ & $16.99 \pm 4.70 \mathrm{ab}$ & $10.33 \pm 0.90 \mathrm{a}-\mathrm{e}$ \\
\hline LI-1 & $230.00 \pm 20.00 b c$ & $9.40 \pm 0.93 \mathrm{ab}$ & $426.67 \pm 45.09 b c$ & $14.92 \pm 2.33 \mathrm{a}$ & $386.67 \pm 15.28 \mathrm{abc}$ & $14.83 \pm 0.97 \mathrm{ab}$ & $10.43 \pm 0.76 \mathrm{a}-\mathrm{d}$ \\
\hline LI-0 & $200.00 \pm 20.00 \mathrm{~cd}$ & $8.12 \pm 0.82 b$ & $430.00 \pm 26.46 b c$ & $16.98 \pm 0.48 \mathrm{a}$ & $366.67 \pm 11.55 \mathrm{abc}$ & $16.11 \pm 1.78 \mathrm{ab}$ & $9.97 \pm 0.32 \mathrm{c}-\mathrm{e}$ \\
\hline LI-PVP3 & $264.13 \pm 12.59 \mathrm{a}$ & $9.95 \pm 0.41 \mathrm{a}$ & $466.67 \pm 11.55 \mathrm{ab}$ & $18.84 \pm 1.00 \mathrm{a}$ & $412.00 \pm 26.46 \mathrm{a}$ & $17.72 \pm 1.23 \mathrm{a}$ & $11.43 \pm 0.12 \mathrm{a}$ \\
\hline LI-PVP2 & $246.67 \pm 5.77 \mathrm{ab}$ & $9.94 \pm 0.75 \mathrm{a}$ & $446.67 \pm 45.09 \mathrm{abc}$ & $17.90 \pm 2.34 \mathrm{a}$ & $406.67 \pm 50.33 \mathrm{ab}$ & $16.09 \pm 1.07 \mathrm{ab}$ & $11.00 \pm 0.40 \mathrm{ab}$ \\
\hline LI-PVP1 & $231.33 \pm 22.03 b c$ & $9.61 \pm 1.22 \mathrm{ab}$ & $443.33 \pm 25.17 \mathrm{abc}$ & $16.40 \pm 2.19 \mathrm{a}$ & $393.33 \pm 5.77 \mathrm{abc}$ & $15.50 \pm 0.46 \mathrm{ab}$ & $10.68 \pm 0.52 \mathrm{a}-\mathrm{d}$ \\
\hline LI-PVP0 & $223.33 \pm 11.55 b c$ & $9.10 \pm 0.82 \mathrm{ab}$ & $400.00 \pm 20.82 c$ & $16.85 \pm 1.61 \mathrm{a}$ & $389.33 \pm 26.46 \mathrm{abc}$ & $15.51 \pm 2.12 \mathrm{ab}$ & $10.13 \pm 0.35 \mathrm{~b}-\mathrm{e}$ \\
\hline LI-SA3 & $249.67 \pm 23.09 \mathrm{ab}$ & $9.11 \pm 1.18 \mathrm{ab}$ & $473.33 \pm 20.82 a$ & $18.29 \pm 1.54 \mathrm{a}$ & $415.33 \pm 10.00 \mathrm{a}$ & $16.99 \pm 3.02 \mathrm{ab}$ & $11.38 \pm 0.67 \mathrm{a}$ \\
\hline LI-SA2 & $243.33 \pm 15.28 \mathrm{ab}$ & $9.27 \pm 0.06 \mathrm{ab}$ & $443.33 \pm 5.77 a b c$ & $17.33 \pm 3.92 \mathrm{a}$ & $370.00 \pm 20.00 a b c$ & $13.32 \pm 0.97 b$ & $10.57 \pm 0.45 \mathrm{a}-\mathrm{d}$ \\
\hline LI-SA1 & $230.00 \pm 20.00 \mathrm{bc}$ & $8.87 \pm 0.86 \mathrm{ab}$ & $430.00 \pm 20.00 \mathrm{bc}$ & $15.40 \pm 2.02 \mathrm{a}$ & $336.67 \pm 30.55 \mathrm{bcd}$ & $14.95 \pm 1.85 \mathrm{ab}$ & $9.97 \pm 0.53 \mathrm{c}-\mathrm{e}$ \\
\hline LI-SA0 & $227.37 \pm 4.56 \mathrm{bc}$ & $8.69 \pm 0.73 \mathrm{ab}$ & $435.00 \pm 15.28 b c$ & $16.77 \pm 1.76 \mathrm{a}$ & $410.00 \pm 36.06 \mathrm{a}$ & $15.59 \pm 1.40 \mathrm{ab}$ & $10.72 \pm 0.51 \mathrm{a}-\mathrm{c}$ \\
\hline$\varnothing \varnothing$ & $106.67 \pm 0.58 \mathrm{e}$ & $5.60 \pm 0.54 \mathrm{c}$ & $246.67 \pm 5.77 \mathrm{~d}$ & $9.10 \pm 10.5 b$ & $190.00 \pm 20.00 \mathrm{e}$ & $7.82 \pm 1.03 \mathrm{c}$ & $5.43 \pm 0.26 \mathrm{f}$ \\
\hline$\varnothing \mathrm{N}$ & $225.07 \pm 8.72 b c$ & $8.74 \pm 0.93 \mathrm{ab}$ & $425.33 \pm 25.17 b c$ & $16.07 \pm 2.56 \mathrm{a}$ & $313.33 \pm 23.09 \mathrm{~d}$ & $12.31 \pm 0.94 b$ & $9.64 \pm 0.53 \mathrm{e}$ \\
\hline $\begin{array}{l}\text { One-way } \\
\text { ANOVA }\end{array}$ & $7.934 * * *$ & $4.254 * * *$ & $17.645 * * *$ & $3.481 * *$ & $8.906 * * *$ & $5.402 * * *$ & $21.446^{* * *}$ \\
\hline \multicolumn{8}{|c|}{ Two-way ANOVA } \\
\hline $\begin{array}{l}\text { Medium } \\
\text { formulation }\end{array}$ & $8.214^{* *}$ & $2.415^{*}$ & $0.619 \mathrm{~ns}$ & $2.029 *$ & $3.926^{*}$ & $0.861 \mathrm{~ns}$ & $2.596 \mathrm{~ns}$ \\
\hline Storage time & $2.066 \mathrm{~ns}$ & $0.083 \mathrm{~ns}$ & $1.364 \mathrm{~ns}$ & $0.435 \mathrm{~ns}$ & $1.539 \mathrm{~ns}$ & $1.052 \mathrm{~ns}$ & $2.575 \mathrm{~ns}$ \\
\hline $\begin{array}{c}\text { Medium } \\
\text { formulation } \\
\times \text { storage time }\end{array}$ & $1.365 \mathrm{~ns}$ & $0.055 \mathrm{~ns}$ & $3.907 * *$ & $0.216 \mathrm{~ns}$ & $0.752 \mathrm{~ns}$ & $0.260 \mathrm{~ns}$ & $1.770 \mathrm{~ns}$ \\
\hline
\end{tabular}

Note. Explanations under Table 1; results were represented as mean $\pm \mathrm{SD}$; significant at $*-P<0.05, * *-P<0.01$ and *** $-P<0.001, \mathrm{~ns}-$ not significant; one- and two-way ANOVA shows $F$ values. 
Table 5. The results of two-way ANOVA for average yield of total shoot dry weight $\left(\mathrm{SDW}_{\text {tot }}\right)$ of alfalfa and total nitrogen $\left(\mathrm{N}_{\text {tot }}\right)$ content during the experimental years (2018-2019)

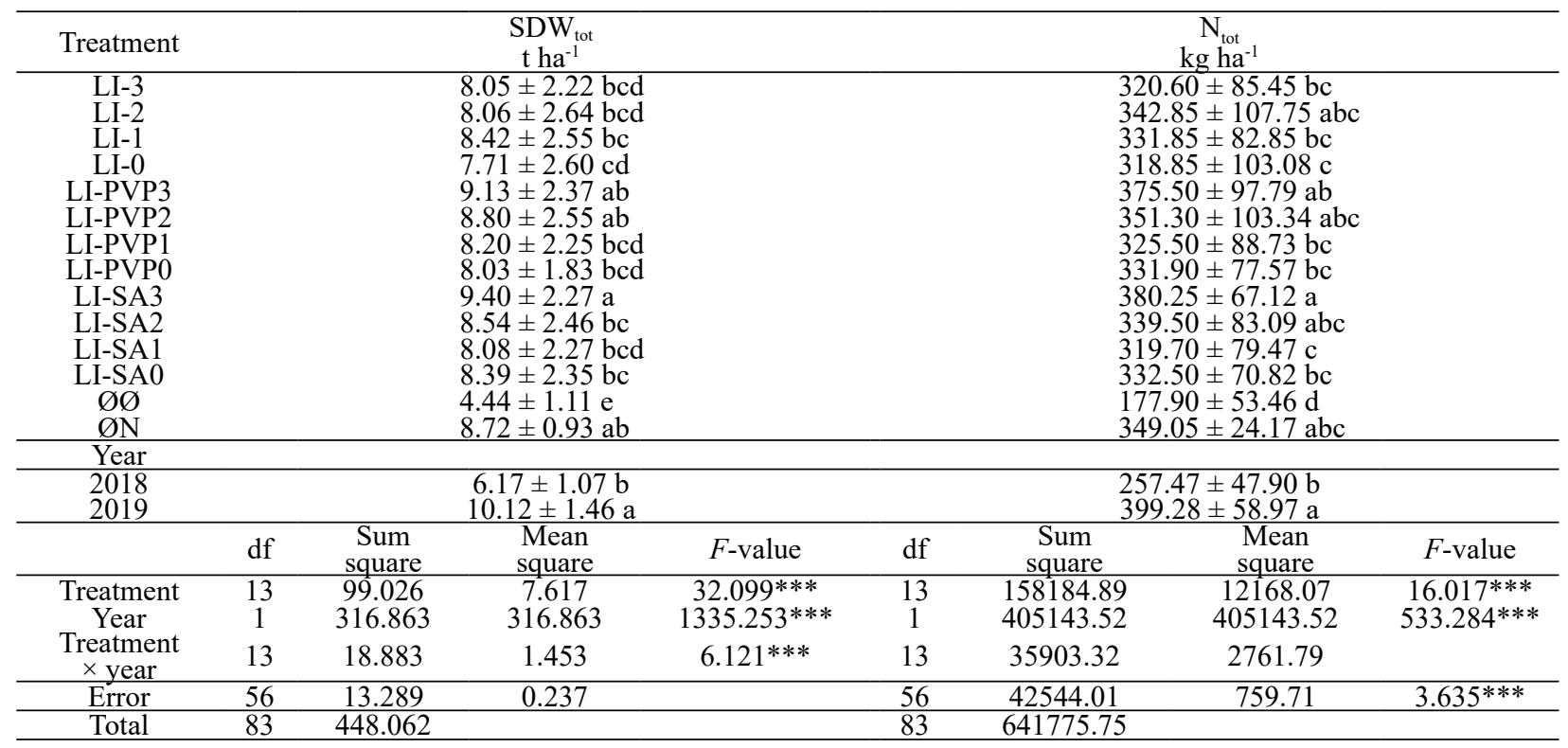

Note. $\mathrm{df}$ - degree of freedom; results were represented as mean $\pm \mathrm{SD}$; significant at $* * *-P<0.001$.

\section{Discussion}

Different microorganisms have shown unequal tolerance to various additives in liquid rhizobial bioinoculants. Choosing the appropriate material for maintaining a high number of microorganisms in the liquid medium is crucial for the development of a new microbial biofertiliser. In addition, these materials should not be toxic to microbes, be environmentally safe, should have a neutral or easily adjustable acidity $(\mathrm{pH})$ and be available locally at a reasonable price (Bargaz et al., 2018; Buntić et al., 2019). Further, the physical and chemical properties of applied additives should protect bacterial cells against desiccation, sedimentation and cell death (Cortés-Patiño, Bonilla, 2015).

Liquid inoculant with sodium-alginate (LISA) or with polyvinylpyrrolidone (LI-PVP) had no detrimental effect on the growth of the rhizobium Siborhizobium meliloti strain 218 (Figure 2). They showed no negative rhizobial culturing conditions compared to the yeast mannitol broth (YMB) as liquid inoculant. On the other hand, agar showed a slightly negative effect on the growth of $S$. meliloti strain 218 . Previous studies on the effect of different additives on the growth of microorganisms in the amended medium showed that agar and SA had negative effect on different rhizobia species such as $S$. meliloti L3Si, Siborhizobium fredii HH103, Bradyrhizobium japonicum USDA110, Azorhizobium caulinodans IRBG23 and Mesorhizobium ciceri USDA2429) (Hartley et al., 2013; Buntić et al., 2019). In contrast, in this experiment, SA was proven to be a good additive to the basal medium of $S$. meliloti strain 218 as well as PVP. In addition, Sehrawat et al. (2015) using PVP at the concentrations of 1\% and 2\% in liquid inoculants showed that this additive did not adversely affect the growth of Rhizobium strain MB703. In these media, the growth of rhizobium was also greater than in the YMB.

During the experiment, in all media formulations, the number of viable rhizobia $(S$. meliloti strain 218) decreased with increasing storage time up to 240 days. That was expected, as these additives cannot be used by rhizobial cells as an energy source. In fact, their main role in the liquid medium is to support cell growth and survival (Leo Daniel et al., 2013). Maintaining the higher viable count during storage period is important and limiting factor for the commercialization of liquid inoculants (Trivedi et al., 2005; Buntić et al., 2019).

According to the local legislation, during storage time, the number bacterial cells in the liquid bioinoculant must not drop below $1 \times 10^{8}$ cell $\mathrm{mL}^{-1}$ (Buntić et al., 2019; Puwanto et al., 2019). Figure 2 represents the effect of the storage time on the viability of $S$. meliloti strain 218 in various formulations. The greatest preservation of viable cells occurred in media formulations with LI-SA and LI-PVP during 240 days of storage. This may be due to sticky consistency of these additives, which gives them adhesive properties. Further these properties may protect the cells from desiccation and drying. PVP is capable of detoxifying fermentation media by complexing with the phenolic-type and limiting the retention of toxins in the media (Girisha et al., 2006; Sehrawat et al., 2015). Additionally, this additive has protective property known as colloidal stabilization (Sehrawat et al. 2015).

During the storage period, temperature is also a limiting factor for the efficiency of the bioinoculants. Storage of bioinoculants at low temperatures is generally more suitable for bacterial survival, which was confirmed during this experiment (Figure 2). However, storage at lower than room temperature is not practical and requires additional cost (Deaker et al., 2004). In previous study of Cortés-Patiño and Bonilla (2015), inconsistent results regarding rhizobia survival were obtained. Survival is also influenced by the choice of bacterial strain and additives. SA is proven as good additive in the bioinoculant formulation providing successful survival during 60 days of storage at $28^{\circ} \mathrm{C}$ temperature (Cortés-Patiño, Bonilla, 2015). In contrast to $S$. meliloti strain 218 , rhizobial S. meliloti strain L3Si showed lower survival (only 150 days at room temperature) in the medium formulation with the same concentration of SA (Buntić et al., 2019). Sehrawat et al. (2015) studied the survival of the Rhizobium strain MB703 in mannitol-supplemented liquid bioinoculants with PVP at room temperature. This medium formulation also gave greater survival of the strain used than the one with glycerol and gum arabic.

In the current study, presence of SA and PVP in media formulations provided suitable conditions for S. meliloti strain 218 survival, which was confirmed by unchanged $\mathrm{pH}$ values and protection of cells from 
elevated temperature in relation to $4^{\circ} \mathrm{C}$. Thus, the shelf life of $S$. meliloti strain 218 in a mixture of enrichment with these additives in relation to liquid inoculant (LI) was successfully extended.

Compared to the traditional inoculation, the technique of pre-inoculation of legume seeds brings several advantages: absence of seeds inoculation during sowing facilitates the work of farmers in the field, lowers the overall inoculants' production costs, reduces the amount of liquid inoculants used and diminishes the use of $\mathrm{N}_{\min }$ fertiliser (Delić et al., 2011; Buntić et al., 2019). Preinoculation of alfalfa seeds with SA and PVP as coating polymers can be justified, as the nodule number per plant did not decrease with storage time. These additives create a suitable microenvironment for the rhizobium, but this cannot be said for agar as coating polymer. This reduction of nodulation was associated with dying of rhizobia over time (Buntić et al., 2019). Based on one-way ANOVA, it was observed that all applied treatments had a highly significant effect $(P<0.001)$ on all tested parameters: number of nodules, plant height, SDW and $\mathrm{N}_{\text {tot }}$ content. The greatest influence had media formulations with SA and PVP: LI-PVP0, LI-SA0, LI-SA3, LI-PVP3 and LIPVP2. However, the test tube experiment included small amount of pre-inoculated seeds, and these observations had to be confirmed in the field.

Field experiment showed similar results to those obtained in the tube experiment. The medium formulations with LI-SA and LI-PVP had an extremely significant effect on the tested parameters - SDW and $\mathrm{N}$ content. In particular, treatments LI-PVP3 and LI-SA3 gave satisfactory effect and confirmed the efficiency of designed novel rhizobial bioinoculants for pre-inoculation of seeds. Considering the two parameters together, the formulation with LI-SA in terms of alfalfa quality ( $\mathrm{N}_{\text {tontent }) \text { and the yield of SDW }}$ could be preferred (fable 5). In addition, due to the highly effective $S$. meliloti strain 218 used in this experiment as the active agent of the bioinoculant, the quality of plants, whose seeds were inoculated before sowing using LI-SA and LIPVP formulations, was better than the control treatment with $\mathrm{N}_{\text {min }}(\varnothing \mathrm{N})$ in the $2^{\text {nd }}$ year of field experiment. It can be explained by the fact that a highly effective rhizobial strain was used in the microbial formulations. In addition, the formulation additives (carriers) used did not interfere with the growth of the rhizobium and did not affect its effectiveness in processes of symbiotic $\mathrm{N}$ fixation.

Differences in the alfalfa $\mathrm{SDW}_{\text {tot }}$ and $\mathrm{N}_{\text {tot }}$ content between the experimental years were expected. This is also correlated with the fact that the genetic potential of alfalfa depends on its life stage and age, as alfalfa is a perennial crop (Tucak et al., 2017). The higher yield obtained in the $2^{\text {nd }}$ year is in accordance with studies by other authors (Tucak et al., 2017; Tlahig et al., 2021). They have shown that maximum yield potential is achieved in the $2^{\text {nd }}$ year of alfalfa cultivation.

Furthermore, 2018 and 2019 were the warmest years in Serbia since meteorological measurements were performed. The amount of precipitation was moderate for both years but was higher in 2018 (RHSS http://www. hidmet.gov.rs/ciril/meteorologija/klimatologija_godisnjaci. php). The total SDW in the $2^{\text {nd }}$ year was higher than in the $1^{\text {st }}$ one, although in 2019 it was warmer and there was less precipitation. The yield obtained in both experimental years is in line or somewhat lower compared with previously published result for normal temperature conditions (Katić et al., 2011). However, according to Tucak et al. (2017), alfalfa yield reaches $15.65-22.26 \mathrm{t} \mathrm{ha}^{-1}$ even in dry years Nevertheless, the use of the medium formulation of inoculants with SA and PVP for pre-inoculation of alfalfa seeds gave satisfactory results of alfalfa cultivation improving the yield compared to the control treatment and can be a good choice of alfalfa cultivation at high temperatures.

\section{Conclusion}

The additives sodium-alginate (SA) and polyvinylpyrrolidone (PVP) did not affect the growth of Sinorhizobium meliloti strain 218 and showed a significant positive effect on its survival in liquid rhizobial bioinoculants during prolonged storage up to 240 days (8 months). In the field experiment, the alfalfa shoot dry weight $\left(\mathrm{SDW}_{\text {tot }}\right)$ and $\mathrm{N}$ content in SDW $\left(\mathrm{N}_{\text {tot }}\right)$ (average for two years) stignificantly increased in all pre-inoculated treatments compared to the control. The pre-inoculation technique yielded good results using inoculant formulation with LI-SA3 followed by LI-PVP3. Designed liquid rhizobial bioinoculants with SA and PVP provided double benefits. They can be used for both inoculation and preinoculation. The pre-inoculation method facilitates seeds sowing as well as increases alfalfa yield and its quality (higher $\mathrm{N}$ content in alfalfa plants).

\section{Acknowledgements}

This research was supported by the Ministry of Education, Science and Technological Development of the Republic of Serbia (contract No. 451-03-9/202114/200011).

Received 01022021 Accepted 26072021

\section{References}

Andrews M., Cripps M. G., Edwards G. R, 2011. The potential of beneficial microorganisms in agricultural systems. Annals of Annlied Binlogy, 160 (1): 1-5 https://doi.org/10.1111/j.1744-7348.2011.00519.x

Bargaz A. Lyamiouli K. Chtouki M., Zeroual Y., Dhiba D. 2018. Soil microbial resources for improving fertilizers efficiency in an integrated plant nutrient management system Frontiers in Micrnhinlnoy 9. 1606. https://doi.org/10.3389/fmicb.2018.01606

Biswas B., Gresshott P. M. 2014. I he role of symbiotic nitrogen fixation in sustainable production of biofuels. International Inurnal of Molecular Sciences 15(5)· 7380-7397. https://doi.org/10.3390/ijms15057380

Buntic A. V., Stajkovic-Srbinovic U. S., Knezević M. M., Kuzmanović Đ. Ž., Rasulić N. V., Delić D. J. 2019. Development of liquid rhizobial inoculants and preinoculation of alfalfa seeds Archives of Rinlogical Sciences 71 (2): 379-387. https://doi.org/10.2298/ABS181008062B

Chinnaswamy A., Coba de la Peña 'I., Stoll A., de la Peña Rojo D., Bravo J., Rincón A., Lucas M. M., Pueyo J. J. 2018. A nodule endophytic Bacillus megaterium strain isolated from Medicago polymorpha enhances growth, promotes nodulation by Ensifer medicae and alleviates salt stress in alfalfa nlants. Annals of Annlied Biology, 172 (3): 295-308. https://doi.org/10.1111/aab.12420

Cortés-Patiño S., Bonılla K. K. 2015. Polymers selection for a liquid inoculant of Azospirillum brasilense based on the Arrhenius thermodynamic model. African Journal of Rintechnoloov 14 (32): 5547-7553 https://doi.org/10.5897/AJB2015.14777

Counc1l Regulation (EC) No $834 / 200 \%$ ot 28 June 2007 on organic production and labelling of organic products and repealing Regulation (EEC) No 2092/91. https://eur-lex.europa.eu/ legal-content/EN/TXT/?uri=CELEX\%3A32007R0834

Deaker R., Roughley R. J., Kennedy I. R. 2004. Legume seed inoculation technology - a review. Soil Biology and Rinchemistry $36(8) \cdot 1775-1788$ https://doi.org/10.1016/j.soilbio.2004.04.009

Delic D. 2014. Ризооијалне бактерије у пољопривредно производњи легуминоза [Rhizobial bacteria in agricultural production of legumes]. Belgrade, Serbia, 100 p. (in Serbian).

Delić D., Stajković-Srbinović O., Kuzmanović D., Rasulić N., Mrvić V., Andjelović S., Knežević-Vukčević J. 2011. Effect of bradyrhizobial inoculation on growth and seed yield of mungbean in Fluvisol and Humofluvisol. African Journal of Microhiology Research 5 (23): 3946-3957. https://doi.org/10.5897/AJMR11.689

Girısha H. C., Brahmaprakash G. P., Maliesha B. C. 2006. Effect of osmoprotectant (PVP-40) on survival of Rhizobium in different inoculants formulation and nitrogen fixation in cowpea. Geobios, 33: 151-156. 
Hartley E. J., Gemell L. G., Deaker R. 2013. Some factors that contribute to poor survival of rhizobia on preinoculated leouıme seed Cron and Pasture Science, 63 (9): 858-865. https://doi.org/10.1071/CP12132

Horneck D. A. Miller K. U. 1998. Determination of total nitrogen in plant tissue. Kalra Y. P. (ed). Handbook of Reference Methods for Plant Analysis. Soil and Plant Analysis Counnsil Ins n 75-83

https://doi.org/10.1201/9781420049398.ch9

Katıc S., Mılıc D., Katansk1 S., Karagic Đ., Vasiljević S. 2011 Genetic gain in alfalfa breeding: yield of experimental populations versus released cultivars. Ratarstvo i novrtarstyo, 48 (1): 91-98 (in Serhian). https://doi.org/10.5937/ratpov1101091 K

Kazemi Khaledi N., Saadatmand S., Khavari-Nejad R. A., Nejadsattari T. 2019. Responses of alfalfa influenced by magnetic field and rhizobial inoculant. Iranian Journal of Plant Physioloov 9 (4) $2963-2969$

https://doi.org/10.22034/IJPP.2019.668862

Leo Daniel A. E., Venkateswarlu B., Suseelendra D., Praveen Kumar G., Mir Hassan Ahmed S. K., Meenakshi T. Uzma S., Sravani P., Lakshmi Narasu M. 2013. Effect of polymeric additives, adjuvants, surfactants on survival, stability and plant growth promoting ability of liquid bioinoculants Inurnal of Plant Physinlnoy and Pathology, 1 (2): 1-5. https://doi.org/10.4172/2329-955 X.1000105

Malusá E., Sas-Paszt L., Ciesielska J. 201'2. Technologies for beneficial microorganisms inocula used as biofertilizers. The Scientific World Inurnal 2012: article ID 491206 https://doi.org/10.1100/2012/491206

Naseer I., Ahmad M., Nadeem S. M., Ahmad I., Zahir Z. A. 2019. Rhizobial inoculants for sustainable agriculture: prospects and applications. Giri B. et al. (eds). Biofertilizers for Sustainahle A oriculture and Environment Snringer p. 245-283. https://doi.org/10.1007/978-3-030-18933-4 11

Nešić Z., Tomic Z., Zujovic M., Krnjaja V. 2005. Production characteristics of domestic alfalfa (Medicago sativa L.) cultivars in agroecological conditions of Srem district Rinterhnology in Animal Hushandry, 21 (5-6): 169-174. https://doi.org/10.2298/BAH0502169̋N

Official Gazette of the Kepublic of Serbia No 30/2017-13, $31 / 2018-86$. Rulebook on conditions for classification and determination of quality of plant nutrition products, deviations of nutrient content and minimum and maximum values of allowed deviation of nutrient content and on the content of the declaration and manner of marking plant nutrition products (in Serbian).

Puwanto P., Samosir F.A., Yuwariah Y., Sumadi S., Simarmata T. 2019. Viability of Pseudomonas plecoglossicida and
Rhizobium sp. LM-5 as liquid bacterial fertilizers in various formulated carriers. Sayyed R. Z. et al. (eds). Plant Growth Promoting Rhizobacteria (PGPR): Prospects for Sustainable Agriculture Snringer n 185-193

https://doi.org/10.1007/978-981-13-6790-8 16

Ramli R. A. 2019. Slow release fertilizer hydrogels: a review. Polymer Chemistry $10(45) \cdot 6073-6090$

https://doi.org/10.1039/C9PY01036J

Sampson I., Ogugbue C. J., Okpokwasili G. C. 2016. Production and application of agar-based slow-release fertilizers, in the bioremediation of petroleum hydrocarbon-impacted soil. Rritish Rintechnology Inurnal, 13 (4) 1 1-13. https://doi.org/10.973̈4/BBJ/2016/25955

Sandını I. E., Belanı K. B., Falbo M. K., Pacentchuk F., HuzarNovakowiski J. 2019. Seed treatment and pre-inoculation of soybean: effect of storage period and agrochemicals on the physiological quality of seed and yield. African Journal of A gricultural Research, 14 (3): 151-160. https://doi.org/10.5897/ÁJAR2018.13687

Sehrawat A., Suneja S., Yadav A., Anand R. C'. 2015. Influence of different additives on shelf life of rhizobial inoculants for mungbean (Vigna radiata L.). International Journal of Recent Scientific Research, 6 (5): 4338-4342.

Tlahig S., Karmous I., Gorai M., Jaouadi T., Loumerem M. 2021. Effect of cutting time on the performance of alfalfa (Medicago sativa L.) genotypes cropped in arid environment. Polish Iournal of Fnvirnnmental Studies, 30 (2): 1817-1829. https://doi.org/10.15244/pjoes/124757

Trivedi P., Pandey A., Palni L. M. S. 2005. Carrier-based preparations of plant growth-promoting bacterial inoculants suitable for use in cooler regions. World Journal of Micrnhinlnov and Rintechnolnov 7.1.941-945. https://doi.org/10.1007/s11274-004-6820-y

Tucak M., Popovic S., Cupic 'I., Krizmanic G. 2017. Drought stress responses of alfalfa (Medicago sativa L.) breeding populations. Romanian Agricultural Research, 34: 25-30.

Ugrenović V. M., Filipović V. M., Delić D. I., Popović V. M., StajkovićSrbinović O. S., Buntić A. V., Dozet G. K. 2020. Maintenance of soil fertility on organic farm by modeling of crop rotation with participation alfalfa. Matica Srpska Proceedings for Natural Sciences 138.71-82. https://doi.org/10.2298/ZMSPN2038071U

Vincent J. M. 1970. A manual tor the practical study of the root-nodule bacteria. IBP Handbook No. 15. Blackwell Scientific Publications, $164 \mathrm{p}$.

WRB. 2014. World reference base for soil resources World Soil Resources Renorts No. 106, p. 113. http://www.fao. org/3/i3794en/13794en.pdf

\title{
Liucernos sẻklų apdorojimo ir skystų Rhizobium inokuliantų veiksmingumas pasotintame rudžemyje
}

\author{
A. Buntić1, O. Stajković-Srbinović1, M. Knežević ${ }^{1}$, N. Rasulić1, V. Ugrenović ${ }^{2}$ \\ D. Kuzmanović ${ }^{1}$ D. Delić ${ }^{1}$
}

${ }^{1}$ Dirvožemio mokslo instituto Mikrobiologijos skyrius, Serbija

${ }^{2}$ Dirvožemio mokslo instituto Dirvožemio gerinimo ir erozijos skyrius, Serbija

\section{Santrauka}

Keletą pastarụjų dešimtmečių mėlynžiedès liucernos (Medicago sativa L.) sėkloms inokuliuoti buvo naudojami durpių pagrindu pagaminti bioinokuliantai. Tačiau naudojant skystus inokuliantus arba iš anksto inokuliuotas sẻklas, labai palengvėtų liucernų kaip smulkiasėklių pupinių augalų sėja. Tyrimo metu buvo vertintas keturių skystų preparatų poveikis Sinorhizobium (Ensifer) meliloti 218 kamieno išgyvenamumui ilgai laikant. Natrio alginatas (SA) ir polivinilpirolidonas (PVP) neturejo ịtakos S. meliloti 218 kamieno augimui, tačiau turèjo reikšmingą teigiamą poveiki jo išgyvenimui skystus bioinokulantus laikant 240 dienų. Vertinta sẻklų išankstinès inokuliacijos įtaka azoto (N) fiksacijos efektyvumui liucernos augaluose mėgintuvėliuose ir dvejų metų lauko eksperimento metu. Lauko eksperimentas buvo vykdytas 2018 ir 2019 m. pasotintame rudžemyje (Eutric Cambisol). Liucernos ūglių sausoji masė ir suminis $\mathrm{N}$ kiekis reikšmingai padidejjo iš anksto inokuliuotose sèklose visose terpèse, lyginant su kontroliniu variantu be išankstinès inokuliacijos ir nepridėjus mineralinio N. Didžiausią suminę ūglių sausają masę abiem auginimo metais užtikrino sẻklų išankstinè inokuliacija SA ir PVP iki sèjos likus trims mėnesiams; ūglių masès padidejimas buvo reikšmingas, palyginti su apdorojimu mineraliniu $\mathrm{N}$ antraisiais (2019) tyrimo metais. Tyrimo rezultatai parodè, kad Rhizobium bioinokuliantai su natrio alginatu ir polivinilpirolidonu gali būti naudojami kaip skysti bioinokuliantai liucernų sėklų išankstiniam inokuliavimui.

Reikšminiai žodžiai: išankstinė inokuliacija, Medicago sativa, Rhizobium, Sinorhizobium meliloti, skystujų bioinokulantų sudètis. 